\title{
A Clinicopathological Study of Solitary Thyroid Nodule
}

\author{
G.H.M. Shahidul Haque ${ }^{* 1}$, Md. Jakir Hossain ${ }^{2}$, Sabrina Haque ${ }^{3}$, Md. Anisur Rahman ${ }^{4}$
}

\section{Abstract}

Introduction:Common presentation of thyroid disorders is solitary nodule. A discrete swelling in an otherwise impalpable gland is termed as solitary nodule of thyroid. The majority of solitary thyroid nodules are benign. The incidence of malignancy is 10-20\%, being more common in females with a mean age of 35 years. The object of the study was to identify the incidence of malignancy in solitary nodule thyroid which emphasizes on the early diagnosis and adequate treatment. Materials and Methods: The study was carried out in the department of ENT and Head-Neck Surgery of Rangpur Medical College Hospital, Rangpur and Shaheed Ziaur Rahman Medical College Hospital, Boruga in 50 patients with solitary thyroid nodule from July 2013 to June 2015. Results: The solitary thyroid nodules were seen in 1.76\% of surgical admissions. The mean age of the incidence of solitary thyroid nodule is 35 years. The incidence of malignancy in solitary thyroid nodule is $18.51 \%$. The solitary thyroid nodules were frequent in females than males in the ratio of $6.71: 1$. Conclusion: It is concluded from the present study that a remarkable proportion 10\% of solitary thyroid nodules was malignant with females preponderance which emphasizes on the early diagnosis and adequate treatment.

Keywords: Solitary thyroid nodule, Malignancy, Age, Sex, Incidence.

Number of Tables: 06; Number of References: 19; Number of Correspondences: 04

*1. Corresponding Author:

Prof. Dr. G.H.M. Shahidul Haque

Associate Professor (ENT)

Colonel Malek Medical College, Manikjang.

Email: ghmshaque@gmail.com

Mobile: 01711424006,01875009773

2. Dr. Md. Jakir Hossain

Anesthetist

Sheck Fozitunnesa Muzib KPJ Hospital, Asulia, Dhaka.

3. Dr. Sabrina Haque

EMO

CARe Medical College Hospital, Dhaka.

4. Dr. Md. Anisur Rahman

Junior Consultant

Department of ENT

Upazilla Health Complex, Shibjang, Bogura.

\section{Introduction}

Thyroid swellings are common clinical problem throughout the world ${ }^{1}$. These are also common clinical problem in Bangladesh. Many patients with various thyroid disorders from different parts of the country attend in various hospitals ${ }^{2}$. It is prevalent predominantly in adult females. The incidence of endemic goiter in our country was $10.5 \%$ irrespective of age and sex. The male and female percentage were $7.21 \%$ and $12.37 \%$ respectively ${ }^{2}$. The endemicity varies from district to district in Bangladesh ${ }^{3}$.

A significant proportion of solitary thyroid nodules may turn into malignancy, which demands significant medical attention.
The incidence of carcinoma in cold solitary thyroid nodules is about $15-20 \%$ and $80 \%$ or more are benign ${ }^{4}$. Though available diagnostic tool give some clue regarding exact type of lesion, it is very difficult to determine the type of pathology without performing histopathological examination. Fine needle aspiration cytology has a high diagnostic accuracy ${ }^{5}$.

The importance of solitary thyroid nodule lies in the significant risk of neoplasia compared with other thyroid swellings. Other than neoplasm it may also be cyst, thyroiditis or colloid degenerations etc $^{6}$. The object of the study was to determine the frequency of malignancy in solitary thyroid nodulewhich emphasizes on the early diagnosis and adequate treatment.

\section{Materials and Methods}

Study was conducted in the department of ENT and Head- Neck Surgery of Rangpur Medical College Hospital, Rangpur and Shaheed Ziaur Rahman Medical College Hospital, Bogura, during the period of July 2013 to June 2015. The case records of 50 solitary thyroid nodules were analyzed. The diagnosis of solitary thyroid nodules was based on details history, clinical examination and relevant investigations such as thyroid functions tests (serum $\mathrm{T}_{3}, \mathrm{~T}_{4} \mathrm{TSH}$ level), ultrasonogram, isotope scanning and fine needle aspiration cytology (FNAC). Indirect laryngoscopic examination/video laryngoscopic examination to check the mobility of vocal cords was done before and after surgery. All the patients were operated and the specimen was studied.

Patient below the age of 10 years, pregnant females, those with history of radiation exposure to neck and those with family history of thyroid cancer were excluded from the study.

\section{Results and Observation}

Age of the patients ranged from 10 years to 60 years. But most of the patients were aged in between 3rd and 4th decade. Out of 50 cases, 
$76 \%$ (38 patients) were female and 24\% (12 patients) were male. Female to male ratio was 3.16: 1 . Most of the cases $(60 \%)$ were from middle socio-economic status (Table-1).

Table -I: Age, Sex and Socio-economic status of the subjects $(n=50)$.

\begin{tabular}{llcl}
\hline Parameter & Distribution & $\begin{array}{c}\text { Number } \\
\text { of } \\
\text { subjects }\end{array}$ & Percentage \\
\hline \multirow{2}{*}{ Age } & $0-10$ yrs & 1 & $2 \%$ \\
& $11-20$ & 4 & $8 \%$ \\
& $21-30$ & 21 & $42 \%$ \\
& $31-40$ & 17 & $34 \%$ \\
Sex & $41-50$ & 6 & $12 \%$ \\
& $51-60$ & 1 & $2 \%$ \\
\hline Socio-economic & Female & 38 & $76 \%$ \\
Status. & Male & 12 & $24 \%$ \\
& Middle class & 30 & $60 \%$ \\
& Rich & 7 & $14 \%$ \\
\hline
\end{tabular}

The minimum age of the subjects was 10 years and maximum was 60 . Butthe youngest and the oldest both of the subjects in the study had been suffering from malignant thyroid disease (Table I).

Table -II: Presenting symptoms $(\mathrm{n}=50)$.

\begin{tabular}{lcc}
\hline Symptom & No. of patients & Percentage \\
\hline Thyroid swelling & 50 & $100 \%$ \\
Cervical lymphadenopathy & 3 & $6 \%$ \\
Hoarseness of voice & 1 & $2 \%$ \\
\hline
\end{tabular}

All of the patients presented with visible or palpable swelling in front of neck. Among them $6 \%$ presented with cervical lymphadenopathy and $2 \%$ with Hoarseness of voice (Table II).

Table -III: Consistency of nodule $(\mathrm{n}=50)$.

\begin{tabular}{lcc}
\hline Consistency & No. of patients & Percentage \\
\hline Firm & 41 & 82 \\
Hard & 5 & 10 \\
Cystic & 4 & 8 \\
\hline
\end{tabular}

Most of the nodules ( $82 \%$ ) were firm in consistency, $10 \%$ were hard and minimum (8\%) were cystic. Hardness of the nodules might be due to malignancy (Table III).

Table - IV: Sonological findings $(n=50)$.

\begin{tabular}{lcc}
\hline Findings & No. of patients & Percentage \\
\hline Solid & 39 & $78 \%$ \\
Cystic & 11 & $22 \%$ \\
\hline
\end{tabular}

High resolution ultrasonogram is an unique tool for diagnosing physical characteristics of thyroid gland. By using this tool clinically undetectable thyroid nodule can be categorized (Table IV).

Table-V: FNAC findings $(n=50)$.

\begin{tabular}{lcc}
\hline Diagnosis & No. of patients & Percentage \\
\hline Colloid nodular goiter & 32 & $64 \%$ \\
Colloid degeneration & 5 & $10 \%$ \\
Monomorphic adenoma & 1 & $2 \%$ \\
Adenomatusgoitre. & 1 & $2 \%$ \\
Follicular epithelial cell & 6 & $12 \%$ \\
Papillary carcinoma & 2 & $4 \%$ \\
Not conclusive & 3 & $6 \%$ \\
\hline
\end{tabular}

Cytological diagnosis is highly accurate, minimally invasive preoperative diagnostic tool. In this study it was not conclusive in only $6 \%$ (3) cases, but other finding was conclusive as histopathological reports (Table-V).

Table - VI: Histopathology $(n=50)$.

\begin{tabular}{lccc}
\hline Diagnosis & $\begin{array}{c}\text { No. of } \\
\text { patients }\end{array}$ & Percentage & $\begin{array}{c}\text { Type of } \\
\text { tumor }\end{array}$ \\
\hline $\begin{array}{l}\text { Multi nodular goiter. } \\
\begin{array}{l}\text { Simple nodular } \\
\text { goiter. }\end{array}\end{array}$ & 12 & $38 \%$ & \\
$\begin{array}{l}\text { Multinodular goiter } \\
\text { with cyst formation. }\end{array}$ & 7 & $14 \%$ & \\
$\begin{array}{l}\text { Follicular adenoma } \\
\text { Multi nodular goiter }\end{array}$ & 6 & $12 \%$ & Benign \\
with thyroiditis & 3 & $2 \%$ & \\
\hline $\begin{array}{l}\text { Papillary carcinoma } \\
\text { Follicular carcinoma }\end{array}$ & 2 & $4 \%$ & Malignant \\
\hline
\end{tabular}

Histopathology is an important tool for confirmation of the disease. In this study $90 \%$ of thyroid nodules ware benign and $10 \%$ ware malignant (Table-VI).

\section{Discussion}

Thyroid swellings are common clinical problem in our country ${ }^{1,2}$. Most of thyroid swellings are multi-nodular but a good percentage is solitary thyroid nodule. Thyroid nodules are 3-4 times more frequent in women than men. A nodule may be adenoma, cyst, multinodular goiter, thyroiditis and thyroid cancer. This study was planned to determine the frequency of malignancy in solitary thyroid nodule which emphasizes on the early diagnosis and adequate treatment.

The age distribution of the current study reveals that most of the patients were between 21-30 years (42\%) which is similar to others ${ }^{2,7}$. The youngest subject of the study was10 years male patient which was papillary carcinoma. The oldest subject was 60 years femalepatient, a case of follicular carcinoma ${ }^{2}$. 
Sex distribution shows majority of the patients were female $76 \%$ whereas $24 \%$ were male. Female to male ratio was 3.17: 1 and most of the patients were from non endemic areas ${ }^{8}$. Here we may recall the findings of Kilopatricet al. who found a female to male ratio of $14: 1$ in non endemic areas, which approaching unity $(1: 1)$ in endemic areas 9. There are other two series of two different workers. One shows female and male ratio $2: 1^{2}$, another shows $1.63: 1^{3}$.

Though there is no close relationship between patients with thyroid disease and socio-economic status, the average socio-economic group having higher incidence 60\% followed by poor group $22 \%$ (Table-I). The cause is not exactly known, it might be related to illiteracy, superstitions and fear of surgery.

Regarding presenting complaints we have found that all of the patients with neck swelling present in variable durations. It is also evident that goiter with cervical lymphadenopathy and hoarseness of voice can be present with malignant conditions ${ }^{10}$. Current study detected three cases with cervical lymphadenopathy and one case with hoarseness of voice along with goiter which were diagnosed as malignancies (Table-II). Multi nodular goiter or simple nodular goiter with large swellings may be associated with difficulty in respiration or rarely in deglutition which is mostly due to pressure on trachea or oesophagus ${ }^{11}$.

In the study 41 nodules were firm in consistency out of 50 nodules and there were 5 hard nodules (Table-III). Again out of 5 hard nodules 3 were malignant and other 2 were benign multi nodular goiter. Here hardness is not conclusive but an important indicator for malignancy. It is supported by various authors ${ }^{12,13}$.

All solitary thyroid nodules are not a single clinical entity ${ }^{5}$. So it is very difficult to comment regarding the nature of solitary nodule purely on the basis of clinical ground ${ }^{14}$. But hoarseness of voice, hard irregular nodule, palpable cervical lymph node, extreme of ages and male sex are always suspicious for malignancy in solitary nodule ${ }^{5}$.

Investigations are essential to establish preoperative physical, functional status and cytopathological nature of solitary thyroid nodule ${ }^{15}$. All patients of this study have done thyroid hormone profile and show values within normal limit. On isotope scanning of thyroid gland those nodules which are non- functioning or hypo functioning (cold) are selected for study. Ultrasonography is used to establish physical characteristics and to exclude clinically undetectable nodule of a dominant nodular goiter ${ }^{16}$. On clinical examination 46 nodules were solid and 4 were cystic. In ultrasonography 39 were solid and 11 were cystic (Table-IV). Fine needle aspiration cytology (FNAC) is very important, highly specific, most sensitive, minimally invasive preoperative diagnostic tool ${ }^{5,6}$. In this study, shows 3 FNAC were not conclusive, 47 FNAC were conclusive (Table-V). FNAC diagnosis of this studywas supported by postoperative histopathological reports.
On high resolution ultrasonography and post-operative histopathological study $22 \%$ (11 cases) were diagnosed as cystic lesions associated with various pathology. $10 \%$ to $25 \%$ of solitary were thyroid nodules ${ }^{17}$. In the study cystic lesion were mostly associated with multinodular goiter $(14 \%)$. 5 cases $(10 \%)$ were proved to be carcinoma of which 2 cases $(4 \%)$ were follicular carcinoma and 3 cases (6\%) were papillary carcinoma (Table-VI). According to other studies $10 \%$ to $20 \%$ of cold solitary thyroid nodules are malignant $5,7,18,19$.

\section{Conclusion}

Solitary thyroid nodules are more common in females but more worrisome in males due to the increased incidence of malignancy. FNAC is a very useful procedure for pre operative assessment of solitary thyroid nodule, but malignancy can be still come as a surprise in postoperative histopathological examination. Combined opinion on the nature of the thyroid nodule should be done based on history, clinical examination, ultrasound features and FNAC. Definitive diagnosis is possible only with excision and postoperative histopathological examination of the nodule. It is concluded that as significant proportion of solitary cold thyroid nodules was malignant, so, it is essential to emphasizes on the early diagnosis and adequate treatment.

\section{Conflicts of Interests: None.}

\section{Acknowledgement}

I would like to thanks the following personals who have inspired me and giving consent support for preparing the article.

1. Director, Rangpur Medical College Hospiral, Rangpur.

2. Director, Shaheed ZiaurMahman Medical Colege Hospital, Bogura.

3. Dr. Md. Jakir Hossain.

4. Dr. Sabrina Haque.

5. Dr. Anisur Rahman.

\section{References}

1. Way L W. Current Surgical Diagnosis and Treatment. 11th ed. London; 2003: 241- 247.

2. Rahman Md, Md. Taibur. Study of the incidence of malignancy in cold solid nodule of thyroid in 40 cases. Dissertation BCPS. 1990: 909-910.

3. Wasey A.E, Abdul Md. Solitary cold thyroid nodule. Dissertation BCPS. 1990: 849-850.

4. Matheson N A. The diagnosis of thyroid swellings. Recent advances in surgery 12, Edinburgh. London: Churchill Livingstone. 1986: 179-196.

5. Rains AJH, Charles VM. Bailey and Love's short practice of surgery. 23rd ed. London: ELBS; 2000: 707733.

6. Block MA, Dailey GE, Robb JA. Thyroid nodule indeterminate by needle biopsy. Am J Surg. 1983; 20: 113-203.

https://doi.org/10.1016/0002-9610(83)90262-3 
7. Miller JM. Evaluation of thyroid nodules. Surg. Clin. N. Am. 1985; 69(5): 1063- 1076.

https://doi.org/10.1016/S0025-7125(16)31006-9

8. Inder JC, David HS. Thyroid function tests and there alteration by drugs. The thyroid nodule. Clinical nuclear medicine. 1977; 2 (9): 324- 333.

9. Ashraf SA, Matin ASMR. Review of thyroid disease in Bangladesh. Analysis of personal series of 91 cases. JBCPS. 1984; 2: 5-10.

10. Kendal LW, London RE. Prediction of malignancy in a solitary thyroid nodule. Lancet. 1969; 1: 1071-1073.

https://doi.org/10.1016/S0140-6736(69)91707-3

11. Harmo J, Clark OH. Significance of lymph node metastasis in differentiated thyroid cancer. AMJ. Surg. 1978; 107-112.

https://doi.org/10.1016/0002-9610(78)90209-X

12. Cady B, Sedgwick CE, Meissner WA. Risk factor analysis in differentiated thyroid cancer. Cancer. 1979.

https://doi.org/10.1002/1097-0142(197903)43:3<810::AID -CNCR2820430306>3.0.CO;2-B

13. Charkes ND. Scintigraptic evaluation of nodular goiter. Sem Node Med. 1971; 1: 316-333.

https://doi.org/10.1016/S0001-2998(71)80005-3
14. Kelley DE, Wood RL, AC (eds) Enders. Baileys Test book of Microscopic Anatomy. 18th ed. Baltimore/ London: Williams and Wilkins; 1984: 794-801.

15. Stark DD, Clark OH, Gooding GAW, Moss AA. Highresolution Ultrasonography and computed tomography of thyroid lesions in patients with hyperparathyroidism. Surgery. 1983; 94.

16. Cady B, Cotin K, Rossi RL. The effect of thyroid hormone administration upon survival in patients with differentiated thyroid carcinoma. Surgery. 1983; 94: 978-983.

17. Scheible W, Leopoid GR, Woo VL, Gosinik B. High resolution real time ultrasonography of thyroid nodules. Radiology. 1979; 133: 431-471.

https://doi.org/10.1148/133.2.413

PMid:582856

18. Krik RM (ed). General surgical operations. 1st ed. EdinBrugh, London and New York: Churchill livingstone; 1978: 366-369.

19. Clintook JC. The choice of surgical procedure in thyroid neoplasia. Proc of 2nd imperial cancer research fund symposium. London academy press; 1969: 80-96. 